Vol. 5 No. 4 (2021) pp. 467 - 480

Available online at: http://jurnal.umpwr.ac.id/index.php/abdimas/index

p-ISSN: 2580-3492 e-ISSN: 2581-0162

\title{
"Gara-Gara Pagebluk" Film Pendek Dialek Jawa Timur-an Sebagai Media Sosialisasi Protokol Kesehatan Pencegahan Penularan Covid-19
}

\author{
Rani Prita Prabawangi, Megasari Noer Fatanti $₫$, Kun Sila Ananda \\ Universitas Negeri Malang \\ Jl. Semarang No.5, Sumbersari, kec. Lowokwaru, kota Malang, Jawa Timur 65145, Indonesia \\ | megasari.fatanti.fis@um.ac.id $ه \mid$ DOI : https://doi.org/10.37729/abdimas.v5i4.1364 |
}

\begin{abstract}
Abstrak
Kegiatan pengabdian masyarakat ini bertujuan untuk meningkatkan kesadaran serta kewaspadaan masyarakat terhadap penyebaran virus Covid-19 yang semakin bertambah setiap harinya. Berdasarkan data statistik dari John Hopkins University, tercatat 203 juta kasus positif Covid-19 sejak tahun 2020 dengan jumlah kematian mencapai 4.29 juta jiwa. Hingga artikel ini ditulis, pemerintah pusat bersama dengan pemerintah daerah telah melakukan sosialisasi pencegahan dan penularan virus Covid-19 melalui berbagai media, seperti iklan layanan masyarakat, poster, siaran radio, dan publisitas media. Sejauh ini, materi sosialisasi masih menggunakan bahasa ilmiah sehingga tak jarang masyarakat kesulitan memahami makna dari pesan yang disampaikan. Berdasarkan kondisi tersebut, tim pengabdian merancang bentuk sosialisasi pencegahan Covid-19 melalui media film pendek dengan menggunakan dialek atau logat Jawa Timur- an dengan konsep humor. Tujuannya agar pesan terkait protokol kesehatan dapat diterima, diingat, dan dipraktikkan oleh warga Jawa Timur. Penggunaan dialek Jawa Timur juga bertujuan untuk mengurangi kesenjangan pengetahuan dalam pesan kesehatan yang dikelola oleh pemerintah pusat melalui Gugus Tugas Nasional Covid-19 dengan warga biasa. Dari hasil pre-test dan post-test, kami menemukan bahwa film pendek mampu menjadi sarana edukasi kesehatan, dimana jumlah responden yang berada dalam kategori sangat paham meningkat secara bervariasi dari 35 - 80\% dalam setiap kategori. Hasil positif ini kami harap dapat menjadi langkah awal pengembangan dan penggunaan kontenkonten kreatif yang diproduksi baik untuk kepentingan selama pandemi Covid-19 maupun tujuan edukatif lainnya.
\end{abstract}

Kata Kunci: Edukasi kesehatan, Film pendek, Promosi kesehatan, Covid-19

cc) (7) (8) This work is licensed under a Creative Commons Attribution-NonCommercial 4.0 International License

\section{Pendahuluan}

Sejak temuan kasus pneumonia galur baru di Wuhan, Cina pada akhir Desember 2019, pemberitaan media massa global tak luput dengan perkembangan jumlah temuan kasus baru setiap harinya. Otoritas badan kesehatan dunia, World Health Organization (WHO) mengumumkan penetapan status Kedaruratan Kesehatan Masyarakat yang Meresahkan Dunia (Public Health Emergency of International Concern), selanjutnya disebut pandemi global pada bulan Maret 2020, dengan alasan penambahan jumlah kasus aktif yang cukup signifikan di beberapa negara, salah satunya Indonesia. Tingkat penyebaran yang cukup tinggi dan dampak keparahan kondisi kesehatan yang mengkhawatirkan menjadi alasan utama WHO meminta seluruh kepala negara untuk waspada terkait penyebaran virus Covid-19 ini (NationalGeographic.id, 2020). 
Berdasarkan data yang dikutip dari John Hopkins University per 20 Maret 2020, tercatat sejumlah 4.9 juta orang di seluruh dunia terinfeksi dan 300 ribu diantaranya meninggal dunia akibat Covid-19. Saat tulisan ini dilengkapi pada Agustus 2021, sejumlah 203 juta orang terinfeksi, dan angka kematian menyentuh 4.29 juta jiwa. Angka ini terus bertambah setiap harinya, terlebih dengan munculnya berbagai varian baru, seperti Delta, Gamma, Lampda, dan Kappa. WHO terus meminta kepada seluruh kepala negara dan otoritas kesehatan masing-masing negara (Kementerian Kesehatan) untuk aktif melakukan penapisan virus melalui strategi 3T (testing, tracing, treatment) dan penerapan protokol kesehatan, mulai dari 3M hingga 5M - mencuci tangan, memakai masker, menjaga jarak, menjauhi kerumunan, dan mengurangi mobilitas. Berbagai bentuk kampanye pencegahan penularan virus Covid-19 terus dilakukan, seperti melalui iklan layanan masyarakat di televisi dan surat kabar, media luar ruang, dan konten-konten kreatif di media sosial.

Indonesia sebagai salah satu negara di kawasan Asia Tenggara yang jumlah kasus positif Covid-19 hingga bulan Agustus 2021 mencapai 3.67 juta jiwa dengan jumlah kematian sebanyak 107 ribu masih terus melakukan pengetatan mobilisasi penduduk agar laju penyebaran dapat dicegah. Meskipun awal mula identifikasi kapan virus Covid-19 sebenarnya masuk ke Indonesia masih menjadi perdebatan, namun bulan Maret 2021 lalu, tepat 1 tahun 'masa tinggal' virus korona menjadi bagian dari keseharian masyarakat Indonesia. Tercatat, 2 Maret 2020, melalui konferensi pers di Istana Negara, Presiden Joko Widodo bersama Dr. dr. Terawan Agus Putranto yang saat itu masih menjabat sebagai Menteri Kesehatan mengumumkan mengonfirmasi kasus positif Covid-19 sebanyak tiga orang dan telah dirawat di RSPM Sulianti Saroso, Jakarta (kompas.com, 2020). Namun, pada kesempatan lain, tim pakar Fakultas Kesehatan Masyarakat Universitas Indonesia (FKM UI) memiliki pendapat yang berbeda. Mereka memprediksi virus Corona telah masuk ke Indonesia sejak minggu ke-3 Januari 2020 (detik.com, 2020).

Terlepas dari perdebatan kapan sesungguhnya virus ini mulai memasuki kawasan Indonesia, kenyataannya adalah virus ini kini telah masuk dan menyebar secara massif pada hampir seluruh daerah di Indonesia. Mematahkan "mitos" dan gurauan yang banyak beredar mengenai kekebalan Indonesia atas virus corona yang dilontarkan oleh beberapa pejabat publik, faktanya, Indonesia mengalami peningkatan kasus dengan sangat cepat pada rentang waktu Juni - September 2020. Hingga dua bulan pasca kasus pertama (20/05/2020), di Indonesia telah terkonfirmasi 19.189 orang positif Covid-19 dan belum menunjukkan gejala penurunan jumlah penderita (covid19.go.id, 2020).

Melihat penambahan kasus harian yang meningkat, mendorong pemerintah pusat membentuk Gugus Tugas Percepatan Penanggulangan Covid-19 dibawah koordinasi BNPB sebagai ketua pelaksana yang bertujuan untuk mengkoordinasikan aktivitas antar lembaga dalam mencegah penyebaran virus Covid-19 di masyarakat (TheJakartaPost.com, 2020). Merujuk pada Keputusan Presiden Nomor 7 Tahun 2020 tentang Gugus Tugas Percepatan Penanganan (GTPP) Corona Virus Disease 2019 (COVID-19) dijelaskan bahwa tugas dari gugus tugas ini yaitu mempercepat penanganan Covid-19 melalui sinergi antar kementerian/lembaga dan pemerintah daerah serta meningkatkan kesiapan dan kemampuan dalam mencegah, mendeteksi, dan merespons terhadap Covid-19. Kegiatan utama yang massif dilakukan oleh Gugus Tugas Covid-19 yaitu kampanye penerapan protokol kesehatan 3M yang selanjutnya berkembang menjadi $5 \mathrm{M}$ sebagai salah satu upaya pencegahan penularan virus. Kasus harian di Indonesia dapat disajikan pada Gambar 1 (Beritasatu Research). 


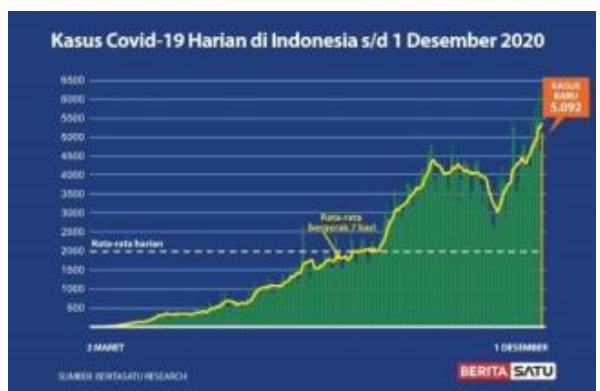

Gambar 1. Kasus Covid-19 harian di Indonesia Maret-Desember 2020

Melalui komunikasi lintas instansi seperti Kementerian Kesehatan dengan Gugus Tugas Covid-19 Nasional, kebijakan pengendalian penularan dan pencegahan virus dapat diputuskan, salah satunya adalah membatasi mobilitas masyarakat yang masih tinggi. Sejak awal pandemi tahun 2020 hingga semester I tahun 2021, kebijakan pembatasan mobilitas masyarakat dimulai dengan istilah PSBB (Pembatasan Sosial Berskala Besar) yang menurut Achmad Yurianto - Juru Bicara GTPP Covid-19 bertujuan untuk mencegah munculnya kerumunan dan berbagai aktivitas publik yang berpotensi menjadi medium penularan virus Covid-19 (kompas.com, 2020). Saat penerapan kebijakan PSBB, pemerintah semakin gencar menyerukan kampanye memakai masker, mencuci tangan pakai sabun atau menggunakan hand sanitizer, dan menjaga jarak selanjutnya disebut dengan 3M, sebagai pencegahan penularan Covid-19 lebih luas. Himbauan untuk menerapkan $3 \mathrm{M}$ atau protokol kesehatan gencar disampaikan pemerintah melalui media massa, seperti televisi, surat kabar, dan radio. Bahkan, tidak sedikit pula anak muda yang berprofesi sebagai pekerja seni atau content creator memproduksi kampanye kesehatan terkait Covid-19 melalui akun media sosial mereka, seperti Instagram, TikTok, dan YouTube. Tujuannya adalah untuk meningkatkan kesadaran warga agar mematuhi himbauan pemerintah untuk tidak mudik saat lebaran tahun 2020 dan menerapkan protokol kesehatan atau 3M dengan ketat.

Sayangnya, himbauan pemerintah terkait mudik dan protokol kesehatan tidak sepenuhnya dipahami oleh seluruh lapisan masyarakat. Sebagai contoh, saat pelarangan mudik lebaran tahun 2020 diterapkan, masih banyak warga yang nekat melakukan perjalanan pulang kampung meskipun dengan cara yang tidak lazim, seperti bersembunyi di dalam truk barang, hingga memanggil jasa derek mobil, agar dapat mudik selama libur lebaran tahun 2020 (Tribunnews.com, 2020). Tidak cukup sampai disitu, jumlah pengunjung ke beberapa pusat perbelanjaan pun mengalami peningkatan pada minggu terakhir bulan puasa tahun 2020. Melansir dari kanal berita (malangpostonline.com, 2020), disebutkan bahwa terjadi peningkatan pengunjung yang cukup signifikan pada pusat perbelanjaan Malang Town Square (MATOS) menjelang penerapan aturan PSBB di Malang Raya. Hal ini menunjukkan bahwa himbauan pemerintah untuk membatasi mobilitas penduduk melalui kebijakan work from home (WfH) dan school from home (SfH) nampaknya belum berjalan efektif. Berdasarkan liputan jurnalis malang-post online, disampaikan bahwa masih didapati pengunjung mal yang tidak tertib menggunakan masker sesuai anjuran pemerintah dan saling menjaga jarak serta menghindari kerumunan seperti ditunjukkan pada Gambar 2 (malangpostonline.com, 2020). 


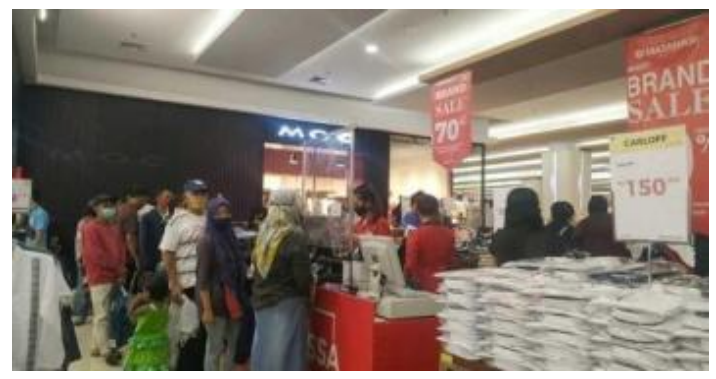

Gambar 2. Masyarakat memadati pusat perbelanjaan di kota Malang

Kurangnya kesadaran masyarakat dalam penerapan protokol kesehatan adalah tantangan utama bagi pemerintah pusat maupun daerah. Selama ini, anjuran/ himbauan pemerintah kepada warga masyarakat untuk menerapkan protokol kesehatan (prokes) terbilang sangat massif. Mengutip keterangan juru bicara GTPP Covid-19, dr. Achmad Yurianto, dalam setiap konferensi pers yang disiarkan secara langsung (live) di televisi setiap pukul 16.00 WIB selalu menekankan pentingnya penerapan protokol kesehatan bagi seluruh warga masyarakat sebagai langkah konkrit pencegahan penularan virus Covid-19 ini.

Namun, faktanya, meskipun himbauan penerapan prokes sangat massif, tidak menghentikan laju penularan virus Covid-19, khususnya di beberapa wilayah yang kasus hariannya masih tinggi, seperti DKI Jakarta, Jawa Timur, Bali, Jawa Barat, dan Jawa Tengah. Fenomena ini menarik perhatian Sosiolog dari Universitas Airlangga Surabaya, Bagong Suyanto, dalam wawancara dengan (detik.com, 2020) mengungkapkan bahwa rendahnya kesadaran masyarakat dalam penerapan prokes disebabkan setidaknya dua faktor. Pertama, komunikasi pemerintah sejak awal pandemi sangat buruk dengan menganggap remeh keberadaan virus Covid-19, dan kedua, penggunaan istilah-istilah selama pandemi yang hanya dapat dipahami oleh kelompok masyarakat terbatas (masyarakat kelas menengah atas atau berpendidikan).

Menurut Bagong, kelompok menengah ke bawah ini justru harus mendapatkan perhatian lebih banyak. Mereka lebih banyak tinggal di kawasan permukiman padat di kota-kota besar yang membuat risiko penularan lebih besar. Kepadatan itu sekaligus membuat kecepatan penularan bisa sangat tinggi dan tak terkendali. "Karena dalam reportase yang diekspos berbagai media mereka melihat yang kena penyakit itu menteri, wali kota, atau orang-orang yang habis bepergian dari luar negeri," ujar Bagong. Akibatnya, bagi kelas menengah ke bawah, penyakit Covid-19 ini justru dianggap sebagai penyakit kelas menengah ke atas.

Merujuk pada laman resmi Covid-19 milik pemerintah Jawa Timur, hingga pertengahan tahun 2020 sebagian besar materi sosialisasi masih banyak menggunakan istilah asing, seperti lockdown, social distancing, physical distancing, droplet, suspect, probable, local transmission, dan new normal. Cukup sulit menemukan infografis atau piranti sosialisasi lain yang menggunakan bahasa sehari-hari yang akrab di telinga sebagian besar masyarakat Jawa Timur. Padahal jika kita menilik definisi kriteria pesan menurut Wilbur Schramm, pesan bukan hanya harus dirancang dan disampaikan secara menarik namun juga menggunakan tanda-tanda yang tertuju pada pengalaman komunikan (Effendy, 2001). Bahasa daerah di sini merupakan perwujudan dari apa yang disebu Schramm sebagai tanda yang tertuju pada pengalaman komunikan (penerima pesan). Selain itu, mengutip hasil riset (Alfarisy, 2020) menyatakan bahwa penggunaan istilah asing selama pandemi Covid-19 semakin menciptakan jarak antara pemerintah dengan warga. Penggunaan bahasa asing juga hanya akan dipahami oleh kalangan terbatas, 
tidak mampu menjangkau warga masyarakat dengan tingkat ekonomi dan pendidikan yang rendah.

Sebagai salah satu daerah dengan jumlah kasus harian aktif Covid-19 cukup tinggi, diperlukan strategi komunikasi krisis kesehatan yang sesuai dengan kultur budaya setempat. Oleh karena itu, tim pengabdian Fakultas Ilmu Sosial, Universitas Negeri Malang merancang program komunikasi berupa film pendek yang menceritakan tentang pentingnya penerapan prokes di lingkup keluarga dengan menggunakan dialek lokal, Jawa Timur-an. Dalam konteks komunikasi kesehatan, kegiatan pengabdian kepada masyarakat ini bermaksud menekankan bahwa, program kampanye atau edukasi kesehatan perlu memperhatikan aspek budaya dari audies sasaran, seperti misalnya penggunaan bahasa lokal. Tujuannya agar supaya pesan kesehatan dapat diterima lebih mudah dan penonton tidak apatis terhadap upaya komunikasi karena terdapat ketidakpantasan dari segi budaya (Crawford \& Okigbo, 2014). Sebelumnya, produktor pesan kesehatan perlu mengikuti pembelajaran, adaptasi, asimilasi terhadap budaya audiens sasaran agar memiliki kompetensi dalam menjembatani kepentingan kesehatan dengan konteks lokal (Burke \& Barker, 2014; Jongen, et.al., 2018).

\section{Metode}

Untuk menyadarkan masyarakat tentang pentingnya melakukan langkah pencegahan penularan Covid-19, kegiatan pengabdian masyarakat ini dilakukan dengan memberikan edukasi kepada masyarakat melalui media audio-visual berbentuk video dua episode berjudul Gara-Gara Pagebluk. Video ini dikemas dalam dua episode dengan durasi masing-masing sepanjang 5 menit dan diunggah pada channel YouTube Untuk Sesama. Video pendek - yang selanjutnya disebut film pendek ini disebarluaskan melalui WhatsApp Group beberapa kelompok sosial seperti karang taruna, PKK, dan kelompok pengajian. Tidak hanya itu, tautan video juga disebarluaskan pada media sosial lain, seperti Instagram, Twitter, dan Facebook. Tujuannya agar semakin banyak audiens yang menonton, harapannya semakin banyak pula masyarakat yang mengetahui pentingnya mematuhi protokol kesehatan guna mencegah penularan Covid-19 di sekitar mereka.

Dalam konteks komunikasi kesehatan, pemilihan media menjadi salah satu faktor penting program kampanye tersebut berhasil atau tidak. Media memiliki kekuatan untuk mempromosikan kesehatan dengan menampilkan model gaya hidup yang dapat diteladani (Marinescu \& Mitu, 2016). Mengutip pendapat (Shin et.al., 2018) setiap sarana yang memiliki kelebihan dan kekurangan. Media sosial misalnya, meskipun memiliki sifat ringkas dan mengundang respons yang cepat, namun masih belum bisa mengimbangi penggunaan media audiovisual, terutama pada aspek narasi dan kronologis yang dapat menyisipkan banyak detail (Shin, et.al., 2018). Atas dasar pertimbangan tersebut, format film senagaja dipilih agar masyarakat mudah mengingat pesan penting tentang penerapan protokol kesehatan sebagai bagian dari pencegahan penularan virus Covid-19 dan media sosial menjadi sarana diseminasi untuk memperlua dan mempercepat proses diseminasi.

Adapun target sasaran dari video Gara-Gara Pagebluk ini yaitu seluruh warga masyarakat Jawa Timur, khususnya warga Malang Raya. Hal ini dapat dilihat dari penggunaan dialek atau logat Jawa Timur-an sepanjang video pendek tersebut. Pemilihan logat/dialek lokal ini tujuannya agar mengurangi kesenjangan makna antara masyarakat urban dan rural di Jawa Timur. Secara spesifik, sasaran video yaitu 
masyarakat dengan tingkat ekonomi menengah kebawah yang (mungkin) kesulitan memahami pesan dari pemerintah terkait Covid-19. Selain itu, video ini bertujuan untuk menumbuhkan, meningkatkan kesadaran masyarakat untuk selalu patuh menerapkan protokol kesehatan dengan sederhana, seperti rajin mencuci tangan dan menggunakan masker. Sejauh ini, masyarakat mengaku kesulitan untuk memahami mengapa perlu menggunakan masker yang dianggap menyulitkan untuk bernafas, terlebih mahalnya harga masker medis yang dianjurkan pemerintah, tidak terjangkau oleh masyarakat dengan tingkat ekonomi rendah.

Pembuatan video pendek ini membutuhkan waktu sekitar 1-1.5 bulan, mulai proses pra-produksi hingga editing. Pengambilan gambar dilakukan di salah satu rumah mahasiswa di Kota Batu, Jawa Timur. Adapun metode yang digunakan dalam kegiatan pengabdian ini yaitu melalui observasi dan wawancara beberapa informan, dari Kota Malang, Kabupaten Malang, dan Kota Batu. Berdasarkan hasil wawancara, tim pengabdian menyusun rencana pengambilan video, mulai dari pemilihan talent, penulisan naskah dengan melibatkan tim ahli dari Satgas Covid-19 Universitas Negeri Malang, dan tim kreatif produksi video. Tahapan pembuatan film pendek dapat disajikan pada Gambar 3.

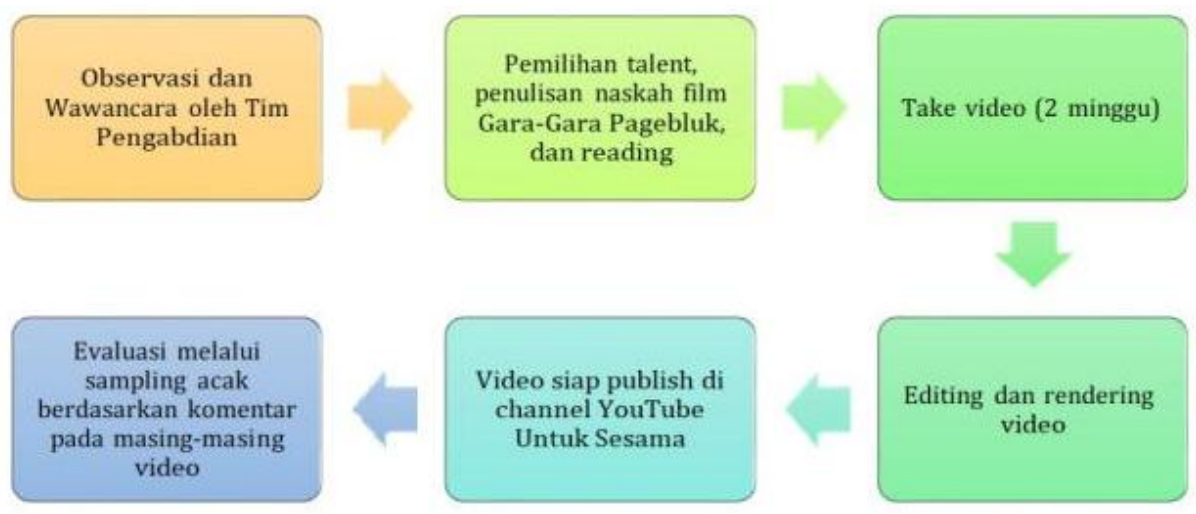

Gambar 3. Tahapan pembuatan video Gara-Gara Pagebluk

Video ini menceritakan sepasang suami istri yang tinggal di wilayah perkampungan padat penduduk. Sepanjang video ini, berbagai dialog terkait pentingnya mematuhi protokol kesehatan selama pandemi, baik itu di lingkungan kerja suami, maupun ketika masuk ke rumah dikemas secara menarik karena diselipkan komentar humor dari kedua pemain film. Naskah video dituliskan dalam bahasa Jawa, khususnya bahasa lokal Jawa Timur dan minim istilah asing atau ilmiah agar mudah dipahami oleh target sasaran dari video Gara-Gara Pagebluk. Meskipun bersifat edukatif, video ini akan tetap memasukkan muatan humor agar informasi yang disampaikan dapat diingat dengan baik dan pada akhirnya meningkatkan partisipasi aktif warga. Sebuah penelitian neurosains mengungkap bahwa menikmati humor dapat mengaktifkan hormon dopamin, yakni senyawa kimiawi di otak yang berfungsi sebagai neurotransmitter dan dapat mempengaruhi perilaku. Dimana hormon tersebut penting untuk menghasilkan motivasi untuk meraih tujuan sekaligus mempengaruhi memori jangka panjang (Goel, 2001).

Adapun pelaksanaan edukasi masyarakat kami laksanakan secara daring dan luring. Secara luring, kami mendatangi beberapa rumah warga di Desa WringinanomPoncokusumo, Kota Batu, sedangkan aktivitas sosialisasi secara dari tentunya dengan menyebarluaskan tautan video. Pilihan untuk melakukan edukasi secara daring bukan 
hanya berdasarkan pertimbangan kondisi pandemi, namun juga fakta bahwa 70\% lebih pengguna layangan internet di Indonesia justru merupakan masyarakat kelas ekonomi menengah ke bawah (Kompas.com, 2018). Sedangkan aktivitas luring kami pilih untuk mengetahui lebih mendalam, kebutuhan informasi yang dibutuhkan oleh warga masyarakat terkait pencegahan Covid-19. Edukasi luring dengan masyarakat dapat disajikan pada Gambar 4.
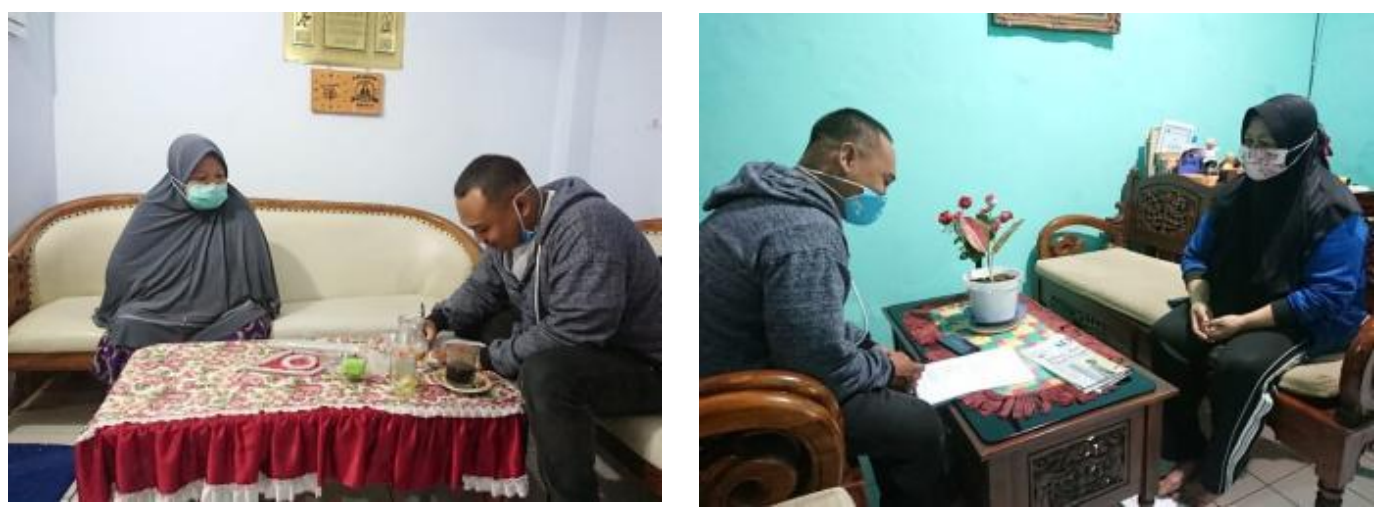

Gambar 4. Edukasi luring dengan warga masyarakat di Kota Batu

Tahapan terakhir dari kampanye kesehatan yaitu evaluasi terhadap audiens yang telah menonton video tersebut melalui aplikasi komentar yang ada di kolom video YouTube. Menurut Crawford \& Okigbo (2014) disebutkan bahwa keberhasilan sebuah kampanye kesehatan tidak terletak pada seberapa komprehensif strategi dan pelaksanaannya, namun juga harus berorientasi pada sasaran audiens untuk mengikuti perubahan perilaku sesuai yang diharapkan pada tahapan inisiasi program.

\section{Hasil dan Pembahasan}

\subsection{Pelaksanaan Kegiatan}

Untuk memberikan edukasi mengenai protokol kesehatan sebelum dan sesudah bepergian di era pandemi kepada masyarakat Jawa Timur, kami merancang dua video pendek yang berdurasi 10 menit. Video pertama berfokus pada apa saja yang harus dibawa saat keluar rumah, khususnya berpergian untuk bekerja atau aktivitas lainnya dan apa yang harus dilakukan saat di luar rumah, sementara film kedua berfokus pada protokol kesehatan setelah bepergian. Video edukasi protokol kesehatan di masa pandemi Covid-19 tersebut bejudul Gara-Gara Pagebluk. Tim pengabdian sengaja menggunakan istilah pagebluk (Bahasa Jawa) yang merupakan padanan kata dari pandemi atau wabah dalam Bahasa Indonesia. Alasan lainnya, judul tersebut selaras dengan isi pesan yang ingin menggambarkan perubahan perilaku yang perlu dijalankan selama pandemi Covid-19 agar mengurangi laju penularan virus di sekitar kita.

Adapun muatan pesan kesehatan yang kami masukkan dalam video tersebut merujuk pada materi sosialisasi pencegahan Corona Virus Disease (Covid-19) yang dikeluarkan oleh berbagai institusi (BNPB, 2020; Klikdokter.com, 2020; Kementerian Kesehatan Republik Indonesia, 2020) yang juga telah kami konsultasikan dengan ahli kesehatan masyarakat serta Satgas Covid-19 Universitas Negeri Malang. Meski telah merujuk pada sumber yang terpercaya, namun konsultasi dengan ahli di bidang 
kesehatan masyarakat menjadi mutlak diperlukan karena dua hal. Pertama, berbagai protokol yang dikeluarkan antar terdapat perbedaan. Alasan kedua, adanya langkahlangkah dan piranti dalam protokol pencegahan Covid-19 tersebut yang dirasa kurang cocok atau sulit dilakukan oleh masyarakat kelompok ekonomi menengah ke bawah. Proses telaah dan konsultasi ini menjadikan pesan yang kami sampaikan bukan hanya efektif mencegah penularan virus Covid-19, namun juga mudah dilakukan oleh masyarakat yang menjadi sasaran kampanye kesehatan ini.

Seperti yang telah disebutkan sebelumnya, dalam memberikan edukasi kepada masyarakat, kami melakukannya secara dalam jaringan (daring) dan luar jaringan (luring). Secara daring, video tersebut telah kami unggah ke kanal Youtube dan telah kami diseminasikan kepada beberapa pihak, seperti kepala RW, ketua PKK, di beberapa daerah di Malang, Batu, dan bahkan Sidoarjo melalui layanan pesan singkat, seperti misalnya melalui WhatsApp. Sementara secara luring, tim kami menyambangi desa Wringinanom- Poncokusumo, Malang. Tim abdimas mendatangi rumah-rumah warga untuk memberikan edukasi protokol keluar-masuk rumah di masa pandemi secara langsung. Dengan tetap memperhatikan protokol kesehatan, kami datang memberikan edukasi dengan cara memutarkan film pendek "Gara-gara Pagebluk". Kami memilih mendatangi rumah warga, mengingat situasi pandemi yang tidak memungkinkan untuk memberikan edukasi kepada sekelompok orang sekaligus. Proses wawancara terhadap warga setelah menyaksikan video disajikan pada Gambar 5.
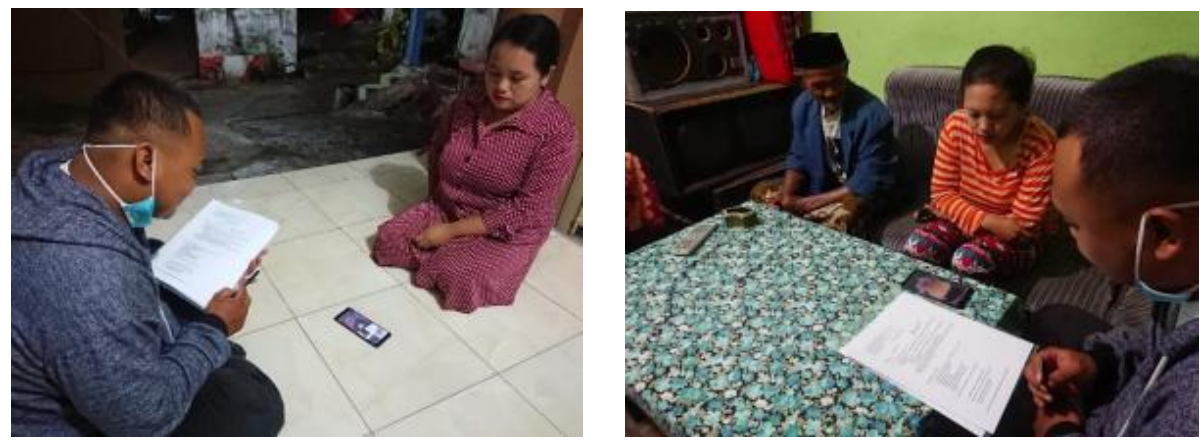

Gambar 5. Wawancara dengan warga setelah video selesai disebarluaskan

Video "Gara-gara Pagebluk" kami unggah pada tanggal 4 Oktober 2020, dan hingga tanggal 25 November 2020, total video tersebut telah ditonton lebih dari 350 kali. Kekuatan video Gara-Gara Pagebluk ada pada intensitas dialog pemain yang menggunakan dialek Jawa Timur-an, dan adegan yang menggambarkan aktivitas keseharian warga biasa. Tim pengabdian sengaja memilih pemain yang sesuai dengan karakter yang diperankan yaitu sepasang suami - istri muda dengan pekerjaan suami sebagai cleaning service di kota, sedangkan istri adalah ibu rumah tangga (IRT). Salah satu scane dari video pendek Gara-gara Pagebluk dapat disajikan pada Gambar 6. 

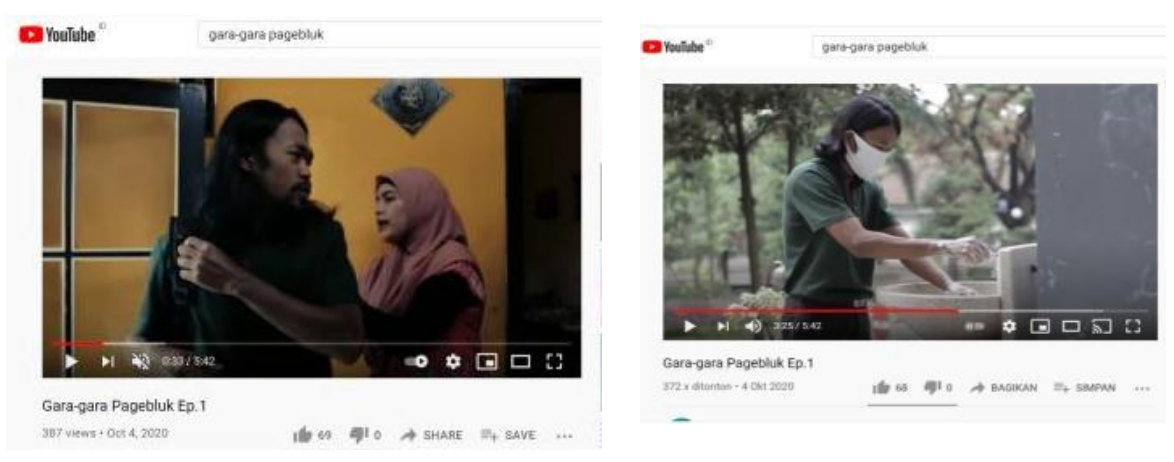

Gambar 6. Potongan adegan dalam video Gara-Gara Pagebluk

\subsection{Pencapaian Hasil Kegiatan}

Selain melakukan edukasi, dalam pelaksanaan pendidikan masyarakat secara luring ini, tim pengabdian kepada masyarakat juga melakukan wawancara dengan warga yang memenuhi kriteria target audiens. Kami mengambil sampel secara purposif dengan kriteria responden berpenghasilan di bawah Rp.2.000.000,- per bulan dan dengan tingkat pendidikan rendah (maksimal SMP/SD/Sederajat). Adapun tujuan tim melakukan wawancara dengan beberapa responden adalah untuk mengetahui secara kualitatif, seberapa jauh pengetahuan warga tentang protokol kesehatan pencegahan Covid-19, seperti pentingnya memakai masker, menjaga jarak, menghindari kerumunan, dan mencuci tangan dengan sabun atau cairan pembersih (hand sanitizer). Adapun beberapa responden yang dapat kami temui mengaku bahwa selama ini menganggap bahwa penerapan protokol kesehatan hanya perlu dilakukan oleh warga kota yang bekerja di kantor-kantor besar, bukan bagi mereka yang berprofesi sebagai pedagang, petani, atau pekerja informal lainnya.

Dengan kriteria tersebut, didapatkan 20 orang sampel (n: 20) dengan rentang usia 23 - 55 tahun. Kepada para responden ini, kami mengajukan sejumlah pertanyaan pada saat sebelum dan sesudah pemutaran video edukasi guna mendapatkan informasi mengenai pengetahuan warga mengenai langkah-langkah pencegahan penularan Covid-19 sebelum dan sesudah menonton video sosialisasi kami seperti ditunjukkan pada Tabel 1. Dengan demikian, tim abdimas dapat memperoleh informasi yang adekuat mengenai dampak video sosialisasi kami terhadap pemahaman masyarakat mengenai pencegahan penularan Covid-19.

Tabel 1 : Hasil Pre-Test Responden

\begin{tabular}{|c|c|c|c|c|}
\hline \multirow{3}{*}{ No } & \multirow{3}{*}{ Aspek Yang Dinilai } & \multicolumn{3}{|c|}{ pre-test } \\
\hline & & Tidak & Cukup & Sangat \\
\hline & & Paham & Paham & Paham \\
\hline 1 & Pengetahuan akan 3M & $15 \%$ & $50 \%$ & $35 \%$ \\
\hline 2 & $\begin{array}{l}\text { Pengetahuan akan cara memakai masker } \\
\text { yang benar }\end{array}$ & $50 \%$ & $30 \%$ & $20 \%$ \\
\hline 3 & $\begin{array}{l}\text { Pengetahuan akan cara dan waktu } \\
\text { mencuci tangan yang baik }\end{array}$ & $40 \%$ & $40 \%$ & $20 \%$ \\
\hline 4 & $\begin{array}{l}\text { Pengetahuan akan barang-barang pribadi yang } \\
\text { perlu dibawa di masa pandemi }\end{array}$ & $50 \%$ & $25 \%$ & $25 \%$ \\
\hline 5 & $\begin{array}{l}\text { Pengetahuan akan protokol kesehatan } \\
\text { sehabis bepergian }\end{array}$ & $80 \%$ & $20 \%$ & - \\
\hline 6 & $\begin{array}{l}\text { Pengetahuan akan proses penularan } \\
\text { virus corona. }\end{array}$ & $40 \%$ & $55 \%$ & $5 \%$ \\
\hline
\end{tabular}


Berdasarkan hasil pre dan post-test yang kami laksanakan, dapat terlihat bahwa pengetahuan responden mengenai langkah pencegahan penularan virus Covid-19 telah bertambah. Setelah menonton video Gara-Gara Pagebluk, tidak ada lagi responden yang masuk ke dalam kategori tidak paham. Pada semua aspek pengetahuan, semua responden dapat memberikan jawaban baik yang sepenuhnya benar maupun sebagian benar. Seperti pada aspek pengetahuan cara memakai masker yang benar, sebelum menonton video masih ditemukan warga yang hanya perlu menutup bagian mulut saja. Selain itu, sebagian besar warga tidak mengetahui bahwa masker perlu diganti setiap 3 jam sekali. Namun setelah mendapatkan edukasi, 85\% warga mengetahui bahwa masker harus menutup bagian hidung dan mulut serta diganti setiap beberapa jam sekali. Tidak hanya itu, masyarakat juga mulai sadar untuk tidak menggunakan tas plastik (kresek) ketika berbelanja, namun mulai beralih menggunakan tas kain yang dapat digunakan beberapa kali. Adegan seperti pada Gambar 7 ini sengaja disematkan dalam video, selain untuk mengedukasi tentang aktivitas sederhana untuk menjaga lingkungan juga mengedukasi bahwa lebih aman dan nyaman menggunakan peralatan yang dibawa dari rumah dibanding membawanya dari luar ketika berbelanja.
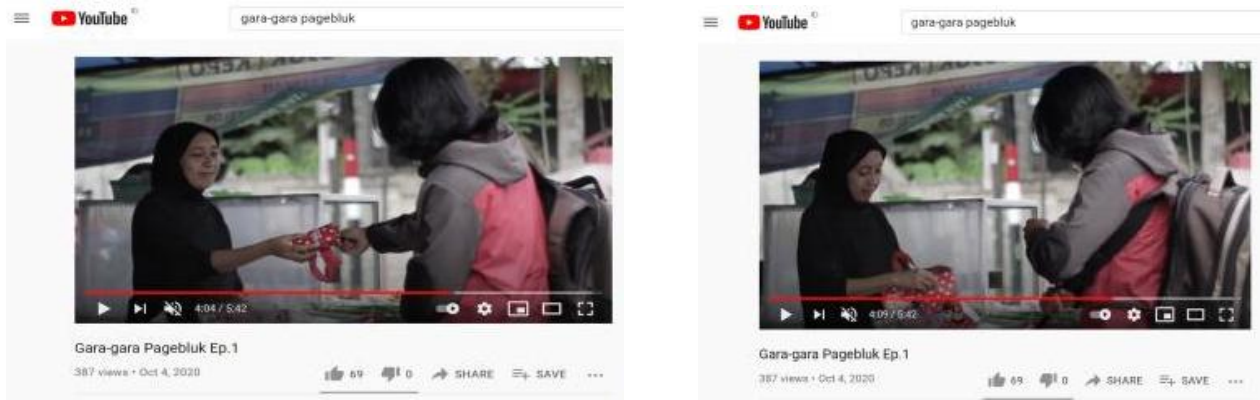

Gambar 7. Potongan adegan menggunakan tas kain ketika berbelanja

Hasil lain yang cukup kentara dapat dilihat pada pemahaman jalur penularan Covid-19. Di mana sebelumnya hanya 1 (5\%) orang warga saja yang mampu menyebutkan droplet sebagai media penularan Covid-19, sementara $40 \%$ lainnya berpikir bahwa virus ini menular hanya melalui udara. Namun setelah melihat video yang kami siapkan, $70 \%$ warga paham bahwa sentuhan dan air liur adalah media penularan virus Covid-19. Hasil post-test dapat ditunjukkan pada Tabel 2.

Tabel 2 : Hasil Post-Test Responden

\begin{tabular}{clccc} 
No & \multicolumn{1}{c}{ Aspek Yang Dinilai } & $\begin{array}{c}\text { Tidak } \\
\text { Paham }\end{array}$ & $\begin{array}{c}\text { post-test } \\
\text { Cukup } \\
\text { Paham }\end{array}$ & $\begin{array}{c}\text { Sangat } \\
\text { Paham }\end{array}$ \\
\hline $\mathbf{1}$ & $\begin{array}{l}\text { Pengetahuan akan 3 M } \\
\text { Pengetahuan akan cara memakai masker } \\
\text { yang benar }\end{array}$ & $0 \%$ & $30 \%$ & $70 \%$ \\
$\mathbf{3}$ & $\begin{array}{l}\text { Pengetahuan akan cara dan waktu } \\
\text { mencuci tangan yang baik }\end{array}$ & $0 \%$ & $40 \%$ & $60 \%$ \\
$\mathbf{4}$ & $\begin{array}{l}\text { Pengetahuan akan barang-barang pribadi } \\
\text { yang perlu dibawa di masa pandemi }\end{array}$ & $0 \%$ & $25 \%$ & $75 \%$ \\
$\mathbf{5}$ & $\begin{array}{l}\text { Pengetahuan akan protokol kesehatan } \\
\text { sehabis bepergian }\end{array}$ & $0 \%$ & $20 \%$ & $80 \%$ \\
\hline $\begin{array}{l}\text { Pengetahuan akan proses penularan virus } \\
\text { corona. }\end{array}$ & $0 \%$ & $30 \%$ & $70 \%$ \\
\hline
\end{tabular}


Menurut hemat kami, untuk meningkatkan pemahaman yang signifikan tidak lepas dari pemilihan bahasa dan istilah yang akrab dengan bahasa sehari-hari masyarakat awam (audiens). Mengacu pendapat (Evers, et.al., 2013) sangat menganjurkan penyematan unsur humor untuk komunikasi kesehatan dengan maksud mengantar audiens memahami pesan kesehatan secara mudah dan cepat, membuat alat komunikasi kesehatan pantas secara sosial dan budaya. Selain itu, penggunaan bahasa sederhana (plain language) penting dalam membantu komunikasi antara pasien dan penyedia layanan kesehatan (Warde, dkk., 2018). Oleh karena itu, penggunaan bahasa daerah Jawa Timur-an pun turut berperan, mengingat bahasa daerah dapat menjadi sarana komunikasi efektif dalam pembangunan (Said, Thalib, \& Banri, 2010).

Senada dengan penelitian tersebut, sebuah survei yang diadakan Pew Research (People-Press.org, 2007) di Amerika menunjukkan bahwa fakta- fakta informatif yang serius ternyata lebih mudah diingat dan diterima saat disampaikan dalam acara komedi satir The Colbert Show ketimbang saat fakta yang sama disajikan dalam berita serius di surat kabar, ataupun kanal berita seperti CNN. Bahkan secara spesifik, dalam studi mengenai literasi kesehatan oleh (Almeida \& Nunes, 2020), humor disinyalir berkontribusi pada pemahaman informasi kesehatan sehingga dapat menciptakan literasi kesehatan yang lebih baik.

\section{Kesimpulan}

Berdasarkan kegiatan pengabdian kepada masyarakat yang telah dilakukan, tim pengabdian menyimpulkan bahwa untuk mendapatkan hasil maksimal ketika mengedukasi warga, terutama pada aspek kesehatan, setidaknya perlu mengetahui kebiasaan dan pola pikir warga sasaran. Tujuannya agar materi edukasi yang diproduksi dapat memenuhi kebutuhan informasi target sasaran. Seperti video GaraGara Pagebluk ini sengaja menggunakan bahasa Jawa, dengan dialek lokal, agar pesan terkait protokol kesehatan (prokes) dapat diterima dan dipraktikkan oleh warga biasa.

Film pendek Gara-Gara Pagebluk yang menggunakan dialek Jawa Timur-an dapat membantu meningkatkan pengetahuan warga Jawa Timur akan protokol keluar-masuk rumah di masa pandemi Covid-19, yang secara tidak langsung dapat menekan resiko penularan virus. Selain itu, berdasarkan hasil pre-test dan post-test dari kegiatan ini didapatkan hasil adanya peningkatan peningkatan pemahaman tentang penggunaan masker yang tepat, pentingnya mandi seusai beraktivitas di luar, dan target sasaran juga mengetahui cara penularan virus Covid-19 jika mereka tidak menjaga jarak dan tidak menggunakan masker yang dianjurkan oleh pemerintah. Tim pengabdian menyadari bahwa edukasi kesehatan selama pandemi tidak cukup dilakukan dalam waktu singkat, oleh karena itu, kami berupaya terus menyebarluaskan video Gara-Gara Pagebluk sampai sekarang dengan harapan masyarakat tidak lalai untuk menaati protokol kesehatan, meskipun data statistik penularan Covid-19 di Jawa Timur melandai. 


\section{Acknowledgement}

Penulis ucapkan terima kasih kepada Lembaga Penelitian dan Pengabdian kepada Masyarakat (LP2M) Universitas Negeri Malang yang telah memberikan hibah pendanaan melalui skema Hibah PNBP Tahun 2020. Tak lupa juga penulis ucapkan terima kasih kepada para talent yang terlibat dalam film pendek Gara- Gara Pagebluk, tim Logika Production, dan kolega kami, Nurnaningsih Herya U. S.KM., M.Kes yang telah membantu mulai dari review hingga reading naskah selama proses produksi film pendek ini berlangsung.

\section{Daftar Pustaka}

Airlangga, RS Universitas. (2020, 03 30). Protokol Masuk Rumah. Retrieved from rsuniversitasairlangga:https://www.instagram.com/rsuniversitasairlangga/?hl=id

Alfarisy, Fitri. (2020). Kajian Budaya: Kebijakan Bahasa di Tengah Pandemi Covid-19. ANUVA, 4(3), hal. 343-353.

Ayu Maharani. (2020, 12 24). Tips Kurangi Risiko Tertular Virus Corona saat Bepergian. Retrieved from Klikdokter.com: https://www.klikdokter.com/infosehat/read/3646146/tips-kurangi- risiko-tertular-virus-corona-saat-bepergian

Beritasatu.com. (2020). Pemerintah Utamakan Mitigasi Virus Corona. Retrieved from Beritasatu.com: https://www.beritasatu.com/kesehatan/608391- pemerintahutamakan-mitigasi-virus-corona

BNPB. (2020, 07 02). 9 Tips Naik Angkutan Umum. Retrieved from https://www.instagram.com/bnpb_indonesia/?hl=id

BNPB. (2020, 06 03). Tas Siaga Covid-19. Retrieved from https://www.instagram.com/bnpb_indonesia/?hl=id

Burke, N. J., \& Barker, J. C. (2014). Health communication 'noise': Insights from medical anthropology. In H.E. Hamilton \& W. S. Chou (Eds.), The Routledge Handbook of Language and Health Communication (pp. 15-28). Routledge.

Covid19.go.id. (2020, 05 20). Retrieved from Covid19.go.id: https://covid19.go.id/p/berita/infografis-Covid-19-20-mei-2020

Detik.com. (2020). Retrieved from Detik news: https://news.detik.com/berita/d4991485/kapan-sebenarnya-corona-pertama-kali-masuk-ri.

Crawford, E. C., \& Okigbo, C. C. (2014). Strategic Communication Campaigns. In

C. C. Okigbo (Ed.), Strategic Urban Health Communication (pp. 11-24). Springer New York. https://doi.org/10.1007/978-1-4614-9335-8

de Almeida, C., \& Nunes, C. (2020). Humor Is Important in Healthcare Relationship? . Open Access Library Journal.

Dewi, R. K. (2020, 03 03). Retrieved from kompas.com: https://www.kompas.com/tren/read/2020/03/03/084500765/positif- terinfeksiindonesia-resmi-masuk-peta-sebaran-virus-corona- global?page $=$ all

Effendy, O. (2001). Ilmu, Teori, dan Filsafat Komunikasi. Bandung: Citra Karya.

Evers, C. W., Albury, K., Byron, P., \& Crawford, K. (2013). Young people, social media, social network sites and sexual health communication in Australia: "This is funny, you should watch it." International Journal of Communication, 7(1), 263-280 
Goel, V. D. (2001). The functional anatomy of humor: segregating cognitive and affective components. Nat Neurosci 4, 237-238.

John A. Banas, N. D.-J. (2011). A Review of Humor in Educational Settings: Four Decades of Research. Communication Education, 115-144.

https://www.klikdokter.com/info-sehat/read/3644583/mau-pandemi-usai-ketahuipentingnya-gerakan-5m-covid-19 (Diakses pada 10 Agustus 2021)

Kementerian Kesehatan Repubik Indonesia. (2020). Pedoman Pencegahan dan Pengendalian Coronavirus Disease 2019 (COVID-19). Jakarta.

Kompas.com. (2018, 02 19). Pengguna Internet Di Indonesia Didominasi Masyarakat Menengah Ke Bawah. Retrieved from Kompas.com: https://ekonomi.kompas.com/read/2018/02/19/170000226/pengguna- internet-diindonesia-didominasi-masyarakat-menengah-ke-bawah

Kompas.com. (2020, 04 07). Retrieved from Kompas.com: https://nasional.kompas.com/read/2020/04/07/17382961/pemerintah- sebutbanyak-manfaat-yang-didapat-dari-psbb-di-jakarta.

Liputan6.com. (2020). Awas Malang Bakal Kewalahan Bila Kasus Covid Terus Naik. Retrieved from Liputan6.com: https://surabaya.liputan6.com/read/4241327/awasmalang-bakal- kewalahan-bila-kasus-Covid-19-terus-naik

Malangpostonline.com. (2020, 05). Retrieved from https://www.malangpostonline.com/Malang-Raya/Kota-Malang/2020-

05/37714/wow-pusat-perbelanjaan-di-kota-malang-diserbu-warga-tak- ada-jarakjelang-psbb

Mappapa, P. L. (2020, 03 21). Istilah Asing Bertebaran Saat Darurat Corona, Perlu Bahasa Lebih Mudah. Retrieved from Detik.com: https://news.detik.com/berita/d4948316/istilah-asing-bertebaran-saat- darurat-corona-perlu-bahasa-lebih-mudah

Marinescu, V., \& Mitu, B. (2016). Emerging Trends in Media and Health Research. In V. Marinescu, \& B. Mitu, The Power of the Media in Health Communication (p. 1). New York: Routledge.

NationalGeographic.id. (2020, 05 20). Who Tetapkan Covid-19 Sebagai Pandemi Global. Retrieved from National Geographic: https://nationalgeographic.grid.id/read/132059249/who-tetapkan- Covid-19sebagai-pandemi-global-apa-maksudnya

People-Press.org. (2007, 04 15). Public Knowledge of Current Affairs Little Changed By News and Information Revolution. Retrieved from people- press.org: https://www.people-press.org/2007/04/15/public- knowledge-of-current-affairslittle-changed-by-news-and-information- revolutions/

Said, M., Thalib, F., \& Banri, A. (2010). Peran Bahasa Daerah Sebagai Sarana Pembangunan Berwawasan Kerakyatan dan Penawar Dampak Negatif Globalisasi. Kongres Internasional Bahasa-Bahasa Daerah Sulawesi Tenggara.

Shin, Y., Miller-Day, M., \& Hecht, M. (2018). Media Literacy and Parent- Adolescent Communication About Alcohol in Media: Effects on Adolescent Alcohol Use. In H. D. O'Hair (Ed.), Risk and Health Communication in An Evolving Media Environment (pp. 12-26). Routledge

TheJakartaPost.com. (2020, Maret 14). Indonesia Scrambles to Contain Coronavirus as Most Hospitals Not Ready. Retrieved from The Jakarta Post: https://www.thejakartapost.com/news/2020/03/13/indonesia- scrambles-tocontain-coronavirus-as-most-hospitals-not-ready.html 
Tribunnews.com. (2020, 05 07). Polisi Masih Temukan Warga Yang Nekat Mudik Dengan Bersembunyi Di Dalam Truk. Retrieved from tribunnews.com: (https://www.tribunnews.com/metropolitan/2020/05/07/polisi-masih- temukanwarga-yang-nekat-mudik-dengan-bersembunyi-di-dalam-truk- barang).

Warde, F., Papadakos, J., Papadakos, T., Rodin, D., Salhia, M., \& Giuliani, M. (2018). Plain language communication as a priority competency for medical professionals in a globalized world. Canadian Medical Education Journal, 52-59.

https://www.youtube.com/watch?v=cd5UE40Ljgs\&t=2s (Diakses November, 2020) 